\title{
Literacy in the Information Age: Examining the Convergence of Information Literacy Instruction and Assessment with Theory and Policy
}

\author{
Marlene Asselin, Associate Professor, Faculty of Education, University \\ of British Columbia, Canada \\ Margaret Early, Associate Professor, Faculty of Education, University of \\ British Columbia, Canada \\ Margot Filipenko, Assistant Professor, Faculty of Education, University \\ of British Columbia, Canada \\ Virginia Lam, Masters in Teacher Librarianship student, University of \\ British Columbia
}

\begin{abstract}
Competencies associated with information literacy are becoming increasingly embedded in literacy policy and curriculum; however, little is known about the extent to which instruction and assessment are aligned with current directives. This paper presents two studies designed to examine the state of instruction and assessment of information literacy in Canadian public education. Findings from these studies showed that although instruction of basic levels of information processes is taking place, there is significantly less emphasis on higher-level aspects of information literacy. In regards to assessment, items related to information literacy are not included on large-scale literacy tests thus potentially affecting how teachers allot their instructional time.
\end{abstract}

Literacy education is situated in a world undergoing major changes. One shift is towards the formation of knowledge-based economies. In Canada, as in many other countries, the education system is being directed by government and industry to prepare students to be successful learners, workers, and citizens for the new knowledge-based economy (Chretien, 2002). Participation in the new economy depends on efficient access to and use of information to communicate and generate knowledge and on competency in such higher level processes as "analysis, synthesis, and evaluation of multiple pieces and forms of information” (Kibby 2000, p. 28; see also Kinzer \& Leander, 2003; Leu, Kinzer, Coiro \& Cammack, 2004; Reinking, McKenna, Labbo,\& Kiefer, 1998). The literacy literature identifies these abilities as part of the "new literacies.”

Although not labeled as "information literacy" many descriptions of new literacies mirror conceptions of information processing and information literacy in the library literature (Asselin \& Dreher, 2004). For example, Leu et al. (2004) state that "new literacies allow us to use the Internet and other ICTs to identify important questions, locate information, critically evaluate the usefulness of that information, synthesize information to answer those questions, and then communicate the answers to others" (Leu et al., 2004, p. 1572). Given that successful participation in the new economy requires competency in the new literacies, new literacies are the "new basics." 
These critical abilities are assuming an increasingly prominent place in educational policy (Australian Council of Deans of Education, 2001; Canadian Ministers of Education in Canada, 1999; Organization for Cooperation and Economic Development, 2001). Driven by current policy, the number of learning outcomes pertaining to the new literacies of the Information Age is increasing in core curriculum (Education Queensland, 2001; International Reading Association and the National Council of Teachers of English, 1996). In this way, information literacy is viewed as an integral part of students' comprehensive literacy development and the responsibility of all teachers.

Paradoxically, concurrent with the increasing awareness of the importance of new and information literacies is a resurgence of the back to basics movement. Legislation in some countries, as No Child Left Behind in the United States, is driving literacy education with its emphasis on traditional basic skills such as phonics and spelling. Thus schools and teachers are currently at a critical juncture as they face inherent contradictions in directives around what forms of literacy to teach. On the one hand they are being exhorted by government, industry and professional associations to expand the notions of literacies taught in schools while at the same time basic skills testing regimes are increasing in frequency, and are ever more powerful determiners of accountability (Hoffman, Paris, Patterson, \& Assaf, 2003). Yet there has been minimum analysis of the extent to which forms of literacy traditionally promoted in large scale assessments, are in fact, those that are most relevant to the new economic and social realities we now face as nations. In the U.S. context, findings from Leu, Ataya \& Coiro (2002) have shown that there is little evidence that state assessment programs address students' abilities in new literacies, including ICT and new media.

As Canadian literacy educators and researchers we felt that it was critical to begin examine the current situation pertaining to instruction and assessment of information literacy in our context. This paper describes the approach we took to address these matters. We report selected findings from our studies of information literacy instruction and assessment to illustrate what can be learned. In the study of instruction we examined the extent to which educators are teaching mandated learning outcomes that represent information literacy as well underlying factors of the school culture that affect the teaching of information literacy (for a complete report see Asselin, in press). In the study of assessment, we investigated the extent to which competencies associated with information literacy are represented in large scale assessment programs (for a complete report see Asselin, Early \& Filipenko, 2004). In this paper, we aim to provide a methodological model for other school systems to adapt in order to examine the state of instruction and assessment of information literacy as well as evaluate the relationship of those practices to new directions in literacy theory and policy. We hope that a shared research agenda across IASL countries will enable a more mutually informed knowledge about information literacy education. 


\section{A Methodological Approach to Examining Information Literacy Instruction and Assessment}

\section{Information Literacy Instruction}

This part of the research program was conducted in a western province in Canada with teacher librarians and teachers of grades 6 and 7 who work in public (nonprivate) schools enrolling over 300 students. Grades 6 and 7 were selected as target groups because that is the time that students have shifted from "learning to read" to "reading to learn.” However, the literature shows literacy instruction remains important throughout schooling as students undertake increasingly complex tasks with increasingly complex texts. Students who are 11 and 12 years old spend significant amounts of time in school engaged in research activities and are expected to use a variety of types of print and digital resources. Success in these activities depends much on the instructional support students receive in literacy generally and in information literacy particularly.

Questionnaires that were developed for each group of respondents (teachers and teacher librarians) with common and unique items (see Appendices A and B). Table 1 displays the major areas of the questionnaires, the constructs composing each area, construct variables, and actual questionnaire items.

Table 1 Information Literacy Instruction Questionnaire Constructs

\begin{tabular}{|c|c|c|c|c|}
\hline Major Area & Constructs & - Variables & $\begin{array}{l}\text { Questionnaire } \\
\text { Teacher }\end{array}$ & $\begin{array}{l}\text { Items } \\
\text { TL }\end{array}$ \\
\hline \multirow[t]{4}{*}{$\begin{array}{l}\text { School and } \\
\text { school } \\
\text { library } \\
\text { culture }\end{array}$} & $\begin{array}{l}\text { Teaching and } \\
\text { learning } \\
\text { environment }\end{array}$ & $\begin{array}{ll}\text { - } & \text { Staff collaboration } \\
\text { - } & \text { Resource/project-based } \\
& \text { learning } \\
\text { - } & \text { Student-centered } \\
\text { - } & \text { Teacher knowledge } \\
\text { - } & \text { Collaborate for } \\
\text { information literacy }\end{array}$ & $\begin{array}{l}5 a \\
5 b \\
5 c \\
3,5 e \\
5 d\end{array}$ & $\begin{array}{l}4 \mathrm{a} \\
4 \mathrm{~b} \\
4 \mathrm{c} \\
3 \mathrm{a}, \mathrm{b}, \mathrm{c}, 4 \mathrm{e} \\
4 \mathrm{~d}\end{array}$ \\
\hline & $\begin{array}{l}\text { Information } \\
\text { Infrastructure }\end{array}$ & $\begin{array}{ll}\text { - } & \text { Networking } \\
\text { - } & \text { Online access } \\
& \text { Quality resources } \\
\end{array}$ & 9 & $\begin{array}{l}5 a \\
5 b \\
5 c\end{array}$ \\
\hline & $\begin{array}{l}\text { Recognition } \\
\text { of importance } \\
\text { of information } \\
\text { literacy }\end{array}$ & $\begin{array}{ll}\text { - } & \text { Research frameworks } \\
\text { - } & \text { Administrator support } \\
\text { - } & \text { Portion of library } \\
\text { - } & \text { Responstructional time } \\
& \text { teaching and assessing }\end{array}$ & $5 f, 13$ & $\begin{array}{l}\text { 6a, 6b, 6e } \\
6 b \\
10 \\
6 d, 11,12\end{array}$ \\
\hline & $\begin{array}{l}\text { School library } \\
\text { uses }\end{array}$ & $\begin{array}{ll}\text { - } & \text { Portion of teachers that } \\
\text { collaborate with TL } \\
\text { - } \\
\text { Frequency of } \\
\text { information literacy } \\
\text { instruction by TL }\end{array}$ & & 7 \\
\hline
\end{tabular}




\begin{tabular}{|c|c|c|c|c|}
\hline & & $\begin{array}{l}\text { - Teacher uses of library } \\
\text { - e.g, during research } \\
\text { projects, for teaching } \\
\text { information literacy }\end{array}$ & 7,8 & 8 \\
\hline $\begin{array}{l}\text { Information } \\
\text { literacy } \\
\text { instruction }\end{array}$ & $\begin{array}{l}\text { Basic level } \\
\text { Critical level }\end{array}$ & $\begin{array}{l}\text { Example: Locate, evaluate, } \\
\text { organize information } \\
\text { Example: Examine } \\
\text { information for bias }\end{array}$ & $\begin{array}{l}\text { - } 14 \mathrm{c}, 14 \mathrm{e}, 14 \mathrm{f}, \\
\text { 14g, 14h } \\
\text { - } 11 \mathrm{a}, 11 \mathrm{~b}, 11 \mathrm{~d}, \\
\text { 11f, } 11 \mathrm{~h} \\
\text { - } 14 \mathrm{a}, 14 \mathrm{~b}, 14 \mathrm{~d} \\
\text { - } 11 \mathrm{c}, 11 \mathrm{e}, 11 \mathrm{~g}\end{array}$ & $\begin{array}{l}\text { - 9c, 9e, 9f, } \\
\text { 9g, 9h } \\
\text { - 9a, 9b, 9d }\end{array}$ \\
\hline $\begin{array}{l}\text { Research } \\
\text { assignments }\end{array}$ & $\begin{array}{l}\text { Constructivist, } \\
\text { process-based } \\
\text { approach }\end{array}$ & 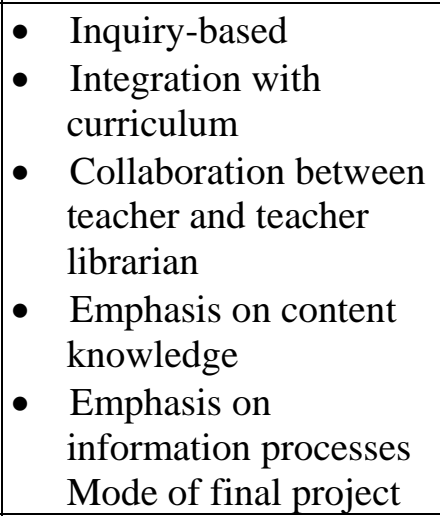 & & \\
\hline Other & $\begin{array}{l}\text { Enabling and } \\
\text { constraining } \\
\text { factors }\end{array}$ & - Open ended question & 12,16 & 12,14 \\
\hline
\end{tabular}

Three major areas of the questionnaires were a) the school and library culture; b) instruction of information literacy processes; and c) request for example research assignments. Each area consisted of several constructs derived from the literature on literacy generally and information literacy specifically.

The school and library culture was represented by four variables as identified in the school library literature as conditions enabling effective information literacy programs (Kuhlthau, 1999; Oberg, 1995, 1999; Zweizig \& Hopkins, 1999): the teaching and learning environment, the information infrastructure available in the school, recognition of the value of information literacy in the school, and school library uses. The school learning and teaching environment was examined by asking about overall staff collaboration, the use of a constructivist approach to teaching and learning, collaborative instruction of information literacy, and teacher knowledge. The construct of information infrastructure was composed of items pertaining to the quality of the school library's print and digital resources, the extent to which the school is networked, and availability of online information, Recognition of the value of information literacy was investigated through questions about shared frameworks of research or information processes at the school, school library, and district levels; principal commitment to the importance of teaching information literacy; allotment of library instructional time given to information literacy; and perceived responsibility for instruction and evaluation of information literacy. Finally, information about how the library is used in the school was gained by determining the portion of teachers who collaborate with the teacher 
librarian, the frequency of information literacy instruction by the teacher librarian, and teachers' uses of the library.

The second major area of the questionnaire addressed instruction provided for a variety of learning outcomes representing information literacy. These information literacy outcomes, taken from core curriculum and information literacy models, were rated by respondents according to the extent of instructional emphasis they placed on each skill. Outcomes were selected to represent a range of aspects of information literacy and two levels ("basic" and "critical”). "Basic" level was defined as skills needed for accessing, locating, and selecting information, and "critical” level, as skills involving critical thinking and using information ethically. The teacher librarian questionnaire included items pertaining to the inclusion of information literacy in evaluation of students' learning. Document collection was the third area of the questionnaire. Both teachers and teacher librarians were asked to submit an example of a research assignment they had used or were planning to use with their grades 6 and 7 classes.

Most items were structured as closed response (Likert and yes/no). Two open-ended items were designed to extend the teacher quantitative data: (a) What factors or conditions enable and/or constrain your ability to teach (information literacy) outcomes? (b) Is there anything you would like to add about the issue of teaching information literacy in the middle grades? A definition of information literacy from a Canadian information literacy document was included as a note at the top of the questionnaire: "proficiency in information retrieval, analysis, and communication in conjunction with highly developed technological skills" (Ontario School Library Association, 1998 - 1999, n.p.)

Descriptive methods were used to analyze the quantitative questionnaire data (frequencies). Responses to the two open-ended questions were analyzed by reading for common themes, sorting, and then regrouping statements until all representative categories were identified. Examples of research assignments that were submitted were coded for evidence of the following features: inquiry-based approach, integration with curriculum, collaboration between teacher and teacher librarian, emphasis on content knowledge, emphasis on information processes (access, evaluate, organize and present), and mode of final project (written, poster, digital).

Packages were sent to 262 qualifying schools in districts that had agreed to participate. Each package contained one teacher-librarian questionnaire and one teacher questionnaire per 25 students in the sample grades. Forty-seven teacher librarian questionnaires (17.9\%) and 97 teacher questionnaires (3.4\%) were returned. However, as it is not known how many principals actually passed on questionnaires to the teacherlibrarians and to grade 6 and 7 teachers, a return rate based on persons who actually received questionnaires cannot be calculated.

\section{Information Literacy Assessment}

This study followed Leu et al. (2002) in which persons responsible for literacy assessment in each of the 50 U.S. states were interviewed about the inclusion of new literacies on state mandated tests. Large scale literacy tests in Canada are a recent development and two of our 13 provinces do not use them. Although these tests do not carry such "high stakes" as those in the U.S., the recent trend to publication of results in the media and on the web are affecting educators' and the public's perception of their purpose and value. 
From the 11 eligible Ministries, two chose not to participate in our study and one did not reply to our request to participate. Our sample also included the Research and Statistics Division of the Council of Ministers of Education in Canada (CMEC) as administrators of the national standardized literacy assessment, the School Achievement Indicators Program (SAIP). In total, we interviewed by telephone persons in seven provinces and one person from the CMEC from September 2003 to April 2004.

Specifically, we investigated (a) the degree to which new literacies are currently being assessed; (b) plans for including new literacies on future measures; and (c) which curricular areas Ministries regarded as responsible for the assessment of new literacies. We restricted the focus of the interview to the same aspects of new literacies used in Leu et al.'s study. In the area of reading, the inclusion of test questions directed to location, comprehension, and evaluation of online information was asked about. A question about the use of word processors to compose responses represented the writing area of new literacies. We adapted Leu et al's scoring rubric to provide a snapshot of national trends by and used qualitative analysis methods to identify emerging themes from the interview data.

Figure 2: Interview Questions: Assessment Practices in Reading and Writing with New

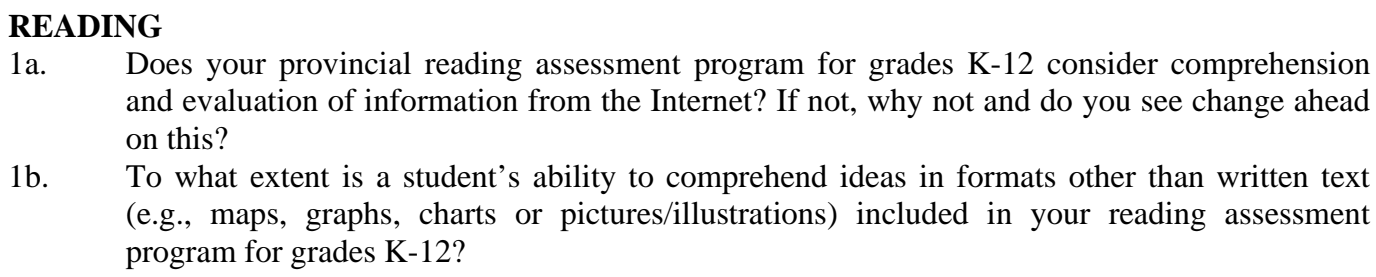

1a. Does your provincial reading assessment program for grades $\mathrm{K}-12$ consider comprehension and evaluation of information from the Internet? If not, why not and do you see change ahead on this?

1b. To what extent is a student's ability to comprehend ideas in formats other than written text (e.g., maps, graphs, charts or pictures/illustrations) included in your reading assessment program for grades K-12?

\section{WRITING}

2a. Does your provincial writing assessment program for grades K-12 permit all students to use a word processor to compose their responses?

\section{PLANNING FOR THE FUTURE}

3a. Do you feel it is likely that your province will permit all students who choose to do so, to use a word processor for your provincial writing assessment, and if so, roughly how many years away is such a decision in your estimation?

3b. Do you feel it is likely that your province will evaluate students' ability to use email effectively, and if so, roughly how many years away is such a decision in your estimation?

3c. Do you feel it is likely that your province will include the comprehension of on-line materials on the provincial reading assessment, and if so, roughly how many years away is such a decision in your estimation?

3e. Do you feel it is likely that your province will include locating and evaluating on-line materials on the provincial reading assessment, and if so, roughly how many years away is such a decision in your estimation?

\section{GENERAL}

4a. Does your province consider each of the following skill areas a reading assessment issue, a writing assessment issue, or a technology assessment issue (or a non-issue for assessment)? using word processors; using email; the comprehension of on-line materials, locating \& evaluating on-line materials

4b. In general, what future directions do you imagine or foresee for your provincial large scale literacy assessments?

4c. What role do the present assessment measures play in your assessment practices? Or educational policies?

4d. What have I failed to ask that you think is important? 
We realize the limited view of new literacies these few abilities represent; however, the tight focus enabled a more "do-able" study, allowed comparability with the United States study, and provided a starting point for examining relationships between assessment and literacy policy and research.

\section{Results: A Snapshot of Information Literacy Instruction in One Province \\ Figure 3. School learning and teaching environment.}

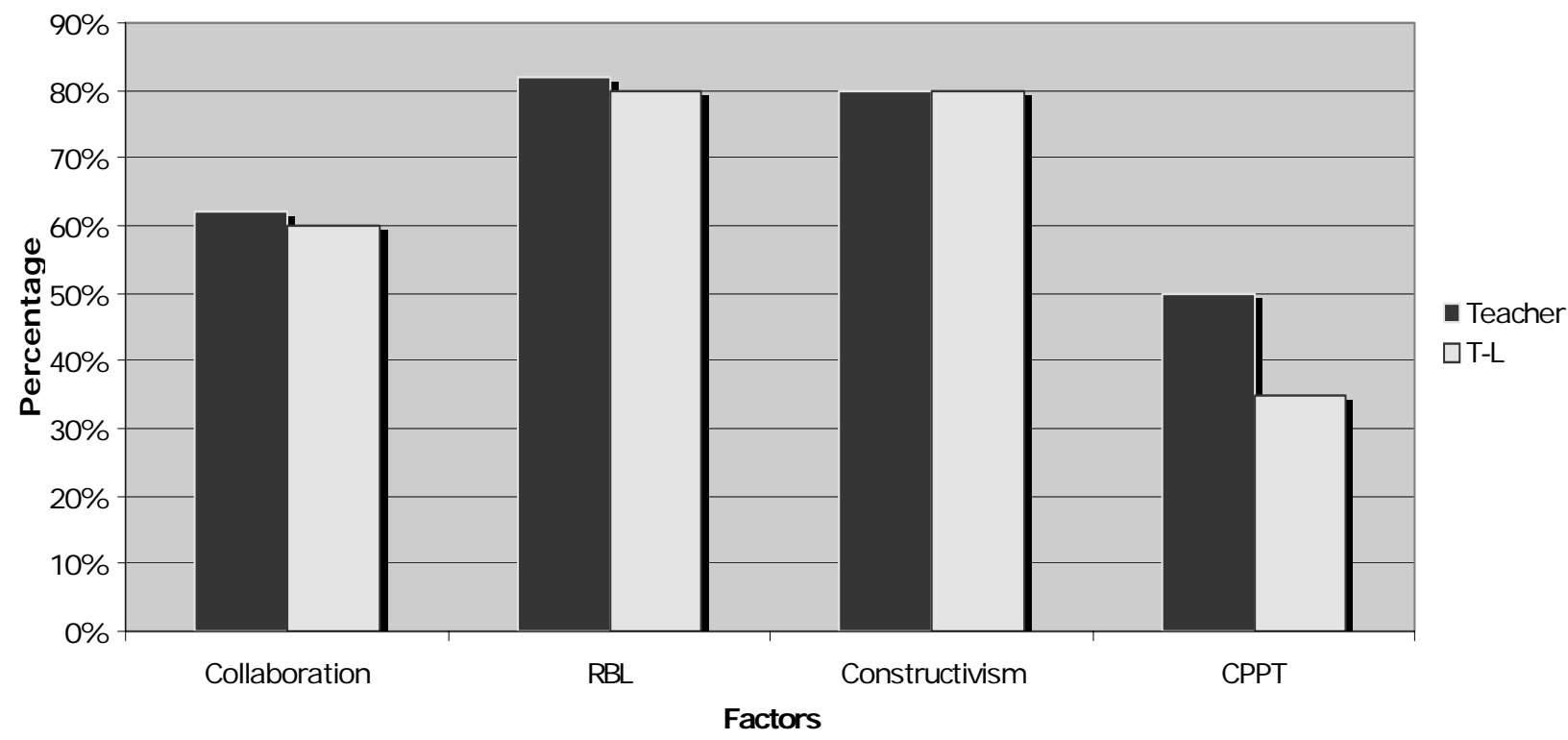

For this paper, we report a sample of results to illustrate how such information can provide an initial look at essential aspects of information literacy in a school system. Specifically, we present some findings about the school and library culture and about the extent of actual information literacy instruction as reported by teachers and teacher librarians.

\section{School and Library Culture}

As seen in Figure 3, the majority of both teachers and teacher librarians reported that three major variables of effective information literacy instruction are in place in their school teaching and learning environment: (a) collaboration between teachers (62\% teachers, 58\% TLs); (b) the use of resource-based and project-based approaches to teaching and learning (81\% teachers, 78\% TLs) and (c) a constructivist or student-centered perspective on teaching and learning (80\% teachers, $78 \%$ Tls). A fourth variable of information literacy instruction, collaborative planning and teaching with the teacher-librarian, was reported to be part of the school culture by fewer teachers (51\%) and by even fewer teacher librarians (34\%). 
Findings based on the percentage of teachers and teacher-librarians that responded with either "agree" or "strongly agree" to statements about the place of these conditions in their schools. RBL $=$ Resource-based learning. CPPT $=$ Collaborative program planning and teaching.

Nearly all teacher librarians (90\%) rated their confidence levels as very high in their understanding of and ability to teach information literacy. Sixty percent of teachers indicated that they feel prepared to teach information literacy and most teachers (90\%) reported that they teach the research process. Most teachers (94\%) claimed that they use the library during research assignments (94\%) and approximately 70\% reported they use the school library for teaching information skills. A significant percentage (77\%) of teachers reported that they understand the role of the teacher librarian while slightly fewer (66\%) teacher librarians thought that teachers in their schools understood their role. When asked how they portion their instructional time, half (49\%) of the teacher librarians indicated that they allot $50 \%$ or more of their time to promoting reading and half (49\%) reported that they allot $25 \%$ or less time to teaching information literacy.

More than half (54\%) of the teachers identified classroom teachers as primarily responsible for teaching information literacy, approximately one-third (31\%) identified teacher librarians, and $15 \%$ named ICT teachers. When asked about evaluation of information literacy, $90 \%$ of teacher librarians reported there was no designated place on their school's report card for this aspect of student literacy achievement. Two-thirds (63\%) of the teacher librarians reported that they did not contribute any evaluative information pertaining to students' information literacy development to classroom teachers; however, one-third (37\%) reported that they passed on written comments on students' progress and marks from their library-based work to teachers but it is unknown if this information is used to write students' report cards.

\section{Information Literacy Instruction}

Both teachers and teacher librarians were asked to determine the extent of instruction they provide on a selection of basic and critical levels of information literacy outcomes. As seen in Figure 4, the majority of both groups of educators reported that they devote significant effort teaching students how to a) access and locate information, b) select appropriate resources for particular purposes, and c) use information technology to support learning. 
Information Literacy Outcomes (From Scope and Sequence framework)

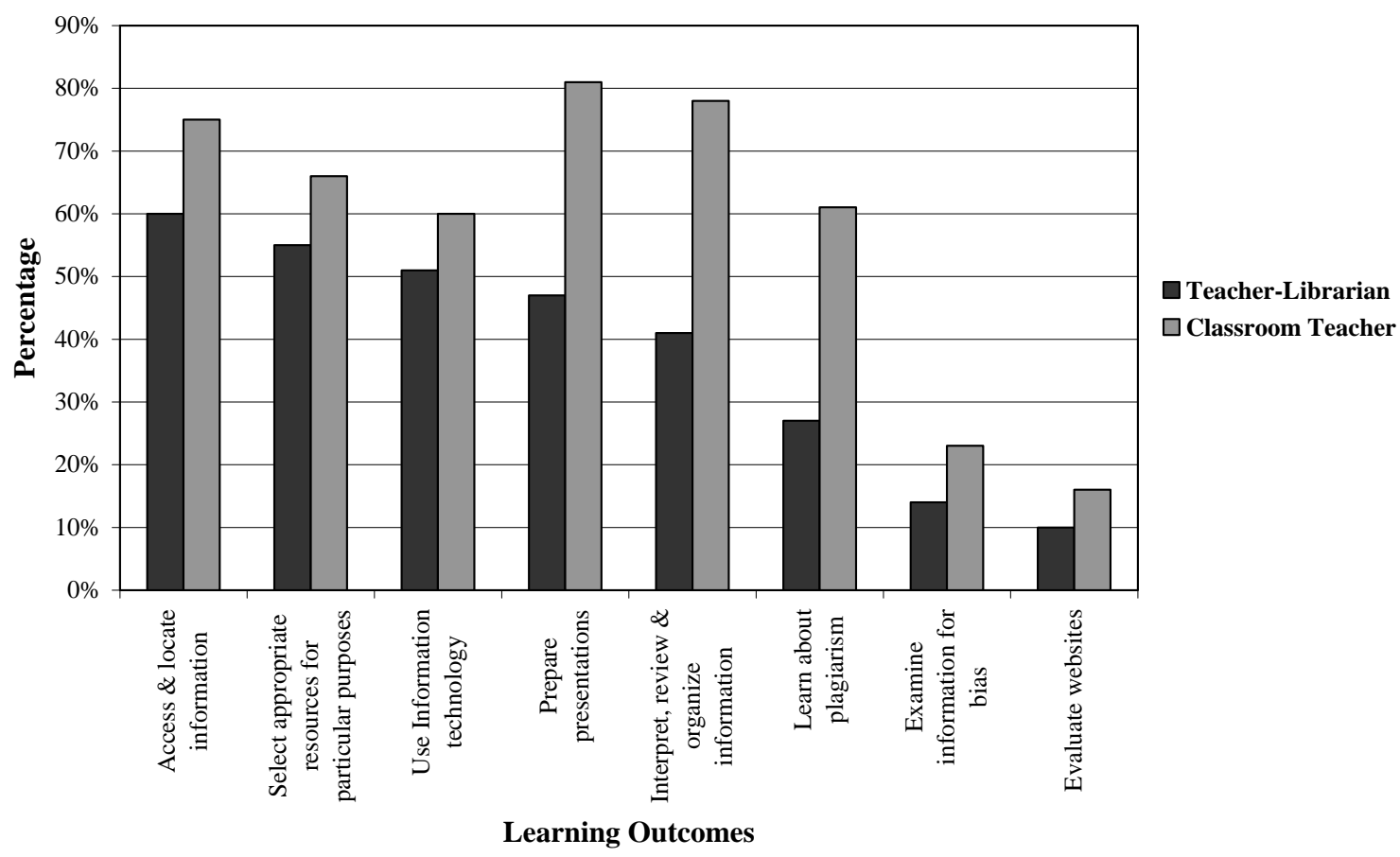

Figure 4. Instructional attention to information literacy outcomes (from library scope and sequence charts).

Findings based on the percentage of teachers and teacher-librarians that rated the extent of instruction they normally provide to their students over the course of a school year as 4 or 5 with 5 indicating "a great deal” and 3 indicating "moderate."

Less time was reported by both teachers and teacher librarians on instruction of three critical dimensions of information literacy: plagiarism, examining information for bias, and evaluating websites.

In examining classroom curriculum only (see Figures 5 and 6), a similar pattern of attention to different aspects of information literacy is apparent. In both grades 6 and 7, most teachers indicated that they attend to locating, recording and organizing information; however fewer teachers reported as much time on the evaluative competencies as represented in the outcomes "evaluate the credibility and reliability of resources" in grade 6, and "analyze information retrieved from electronic resources" in grade 7 . Similarly, although approximately half of the grade 7 teachers rated the amount of time they spend teaching effective and responsible use of information technology as moderate or more, the concern is that half reported spending less than moderate amount of time on those aspects of information literacy. 
Figure 5. Instructional attention to information literacy learning outcomes (grade 6 language arts curriculum document).

Findings based on the percentage of teachers and teacher-librarians that rated the extent of instruction they normally provide to their students over the course of

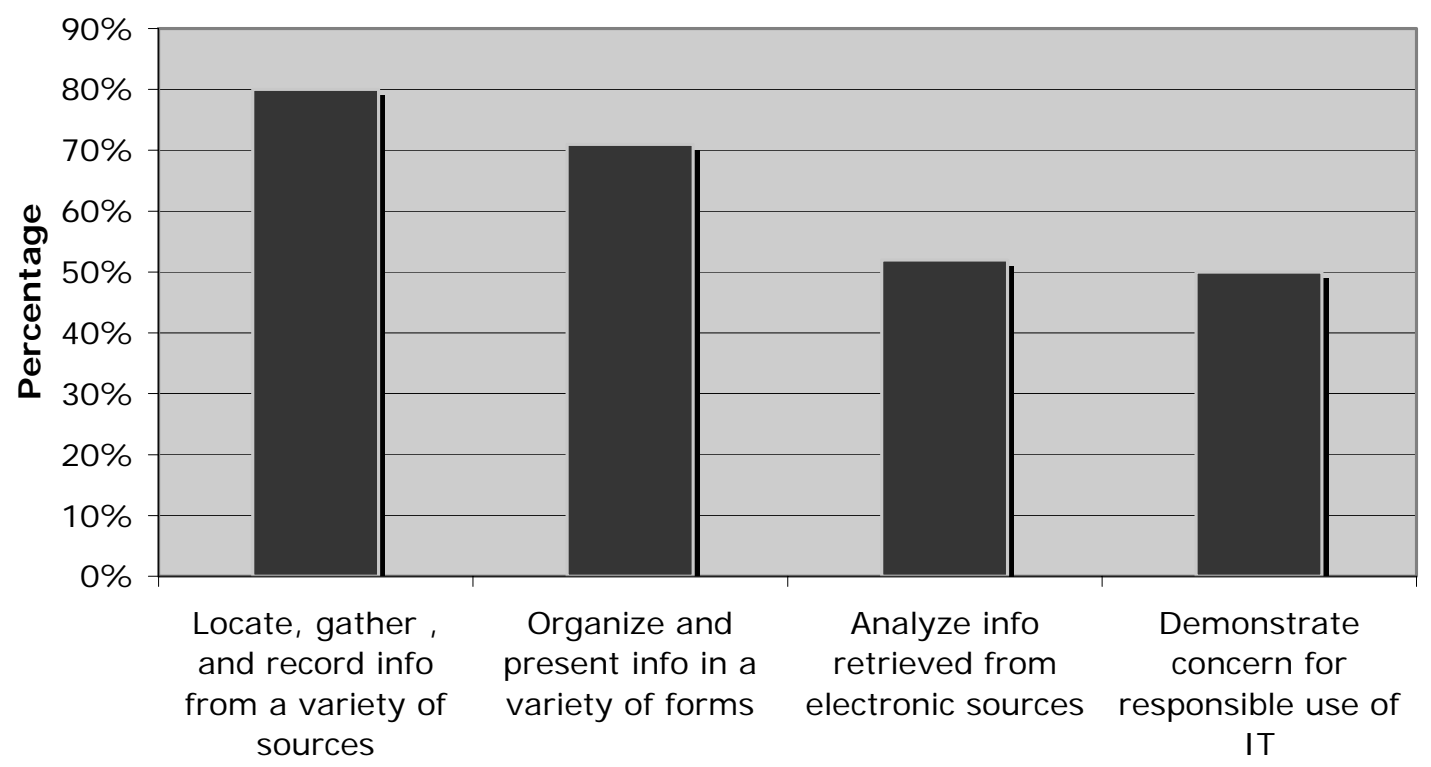

Outcomes

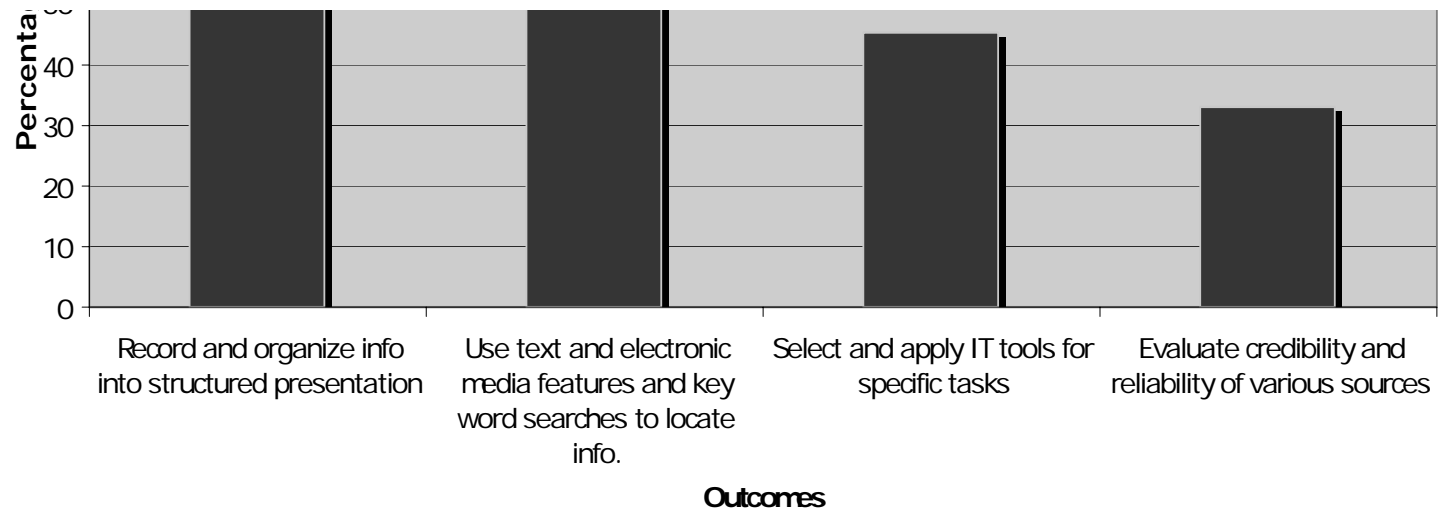

a school year as 4 or 5 with 5 indicating "a great deal” and 3 indicating "moderate.” IT $=$ information technology

Figure 6. Instructional attention to information literacy learning outcomes (grade 7 language arts curriculum document).

Findings based on the percentage of teachers and teacher-librarians that rated the extent of instruction they normally provide to their students over the course of a school year as 4 or 5 with 5 indicating "a great deal” and 3 indicating "moderate." IT = information technology. 


\section{Results: A Snapshot of Information Literacy Assessment in Canada}

Again, we present only selected results from the national assessment study in order to demonstrate the uses of the approach we took. Specifically, we report findings about the place of new literacies in Canadian provincial assessment and accountability systems pertaining to present practices and plans for future assessments.

\section{Present Practices}

Texts used in current large scale assessment instruments in seven of the Canadian provinces include multiple genres and multiple forms of text. Two provinces include representations of electronic texts or web pages either in their reading or writing assessments. For example, students are provided with a topic to write on, given some relevant documents from the Internet, and asked to search for others that either have been preselected or that they find themselves. In this case, the focus of the evaluation is on the resulting writing not the information searching. In another example, students are presented with a print image of Scholastic website and asked such questions as the address of the site, what would happen if they clicked on an icon, and the purpose of one of the sections. One province offers the option of using word processors for the writing assessment with the condition that spell checkers be blocked. Current assessment programs do not include items that specifically address students' abilities to locate, comprehend, or evaluate online information.

\section{Planning for the Future}

Table 2 summarizes present and contemplated practices related to information literacy in large scale assessment programs in Canada.

Table 2 Summary of the Findings of Present and Contemplated Inclusion of Information Literacy on Large Scale Assessment Tests

\begin{tabular}{|c|c|c|c|}
\hline Province & $\begin{array}{c}\text { Information } \\
\text { Literacy Presently } \\
\text { Assessed }\end{array}$ & $\begin{array}{l}\text { Contemplated Information Literacy } \\
\text { for Assessment }\end{array}$ & Time Table \\
\hline$\# 1$ & $\begin{array}{l}\text { - Comprehension } \\
\text { and evaluation } \\
\text { of online } \\
\text { information } \\
\text { - Visual literacy } \\
\text { - } \text { Media literacy } \\
\end{array}$ & $\begin{array}{l}\text { - Use of word processor } \\
\text { - } \quad \text { E-mail } \\
\text { - Locating on-line information } \\
\text { - } \quad \text { Locate, comprehend and } \\
\text { evaluate in an on-line } \\
\text { environment } \\
\end{array}$ & - $2-4$ years \\
\hline$\# 2$ & Visual literacy & $\begin{array}{l}\text { - Comprehension of on-line } \\
\text { materials }\end{array}$ & - 5 - 10 years \\
\hline$\# 3$ & $\begin{array}{l}\text { Visual literacy } \\
\text { Word processing } \\
\text { (with Ministry } \\
\text { Authorization) }\end{array}$ & $\begin{array}{l}\text { - Locate, comprehend and } \\
\text { evaluate on-line materials }\end{array}$ & - $3-5$ years \\
\hline$\# 4$ & Visual literacy & - Word processing & - $2-4$ years \\
\hline
\end{tabular}




\begin{tabular}{|c|c|c|c|}
\hline & & $\begin{array}{ll}\text { - } & \text { Locate, comprehend and } \\
\text { evaluate on-line materials } \\
\text { - } \quad \text { E-mail }\end{array}$ & \\
\hline \# 5 & Visual literacy & $\begin{array}{ll}\text { - } & \text { Word processing } \\
\text { - } & \text { E-mail }\end{array}$ & - $5-10$ years \\
\hline$\# 6$ & - Visual literacy & $\begin{array}{ll}\text { - } & \text { Word processing } \\
\text { - } & \text { Locate, comprehend and } \\
& \text { evaluate on-line materials }\end{array}$ & - Unknown \\
\hline$\# 7$ & - Visual literacy & $\begin{array}{l}\text { Locate, comprehend and } \\
\text { evaluate on-line materials }\end{array}$ & - Unknown \\
\hline
\end{tabular}

Our respondents explained that as curriculum changes to reflect expanded notions of literacy so too will assessments. All provinces are contemplating including at least one "new literacy" on future assessments. Three provinces see this change occurring relatively soon ( $2-4$ years), two in $5-10$ years, and two do not have any definite timeline. One province is "very close" to including comprehension of online materials because it involves building on an existing item about locating online information. Some aspects of new literacies are seen to be more readily included than others. Where one province is planning to include questions that would evaluate students' comprehension of an online text, another is considering including questions to determine students' abilities to effectively navigate between web pages. Three provinces are planning to move assessment measures to online environments.

Major challenges in including new/ICT literacies in large scale assessment programs pertain to (a) conservative concepts of literacy, (b) different understandings of the relationship between technology and literacy than held by literacy researchers; (c) concern for equity of access to and opportunities to use ICT between schools and students; and (d) tensions between political and educational uses of test results.

\section{Discussion}

In these brief sketches of instruction and assessment of information literacy in Canada, it appears that more is being done in instruction, at least in one province, than in large scale assessment programs. Many supportive background factors identified in the literature (Kuhlthau, 1999; Oberg, 1999; Zweizig \& Hopkins, 1999) are at least moderately in place in schools including a shared constructivist philosophy, teacher and teacher librarian knowledge of research processes, and use of the library during class research assignments. As indicated by the much greater portion of time teacher librarians provide to promoting reading than to teaching information literacy, it appears that the more traditional role of the school library program prevails over that of the newer one of teaching information literacy. It follows that teachers may primarily observe teacher librarians promoting reading thus shaping their perception of the role of the teacher librarian. It could be that teachers in this study felt that they are primarily responsible for teaching information literacy perhaps due to this perception of the major role of the teacher librarian as promoting reading, but also likely due to the number of information literacy outcomes that are part of the provincial core curriculum.

Most teachers provide at least a moderate amount of instruction within the "basic" domains of information literacy, specifically accessing, locating, and selecting 
information. However, the majority of teachers and teacher librarians provide less than a moderate amount of instruction in higher level skills and strategies. Current research in both the literacy and library literature shows that these types of abilities are what students need assistance with. Many students are well practiced in the technical new literacy skills such as blogging, instant messaging, online publishing, and downloading —even multi-tasking these activities (Tapscott, 1998; Lankshear \& Knoebel, 2003). However, researchers are identifying areas where they need help: searching and locating information on the Internet, comprehending hypermediated text, and critically evaluating online information (Branch, 2003; Brown, 2001; Coiro, 2003; Kinzer \& Leander, 2003; Schamr-Dobler, 2003).

The lesser support of these critical literacy abilities is echoed in the large scale assessment programs that potentially affect instruction. The International Reading Association (2001) states that “To adequately evaluate students' literacy achievement, reading and writing assessment must include the new literacies that are central to our students' future." As one lens into the political currency of these critical new literacies in Canadian literacy education, we found, as Leu et al. (2002) did in the U.S., that Canadian assessment programs do not yet address students' abilities in the new literacies of ICT and information literacy. Further, we found that they are for the most part some years away from the incorporation of ICT and critical media literacy in any significant way into their assessment measures. Given the actual changes in literacy propelled by new technologies, the already central place of new literacies in young people's out of school lives, and the crucial need for efficient information processing abilities in students' future, addressing the gap between practice and assessment is imperative.

Results of these studies of instruction and assessment of information literacy in Canada revealed trends that indicate ways that teacher librarians can uniquely support schools' expanding literacy programs as they tackle the task of ensuring students are prepared to participate in a global, networked information society. Teacher librarians need to reposition themselves as leaders of the new literacies required for learning and solving problems with the Internet and ICT. In particular there is strong need for instructional leadership in the higher level "new literacy" learning outcomes and in assessment and evaluation of all aspects of the new literacies of the Information Age. Knowing what teachers are already doing is a fruitful starting point for productive collaboration with teachers. In this case, given that teachers are working with research process frameworks and teaching some parts of information literacy, developing collaborative teaching plans of the lesser taught areas-i.e., higher level critical information processes - can be recommended.

Knowing the gap between instruction and large scale assessment can help teacher librarians in Canada understand the significance of the test results compared to the new information literacy skills required for students to participated in a knowledgebased economy. The school library community can also use their knowledge of the place of information literacy in the country's large scale assessment programs to work with policy makers to ensure adequate representation of the literacy competencies students need for their future. This is an important new direction for advocacy because "despite years of debate on the nature of literacy and curriculum and ensuing policy directions, it is assessment--its weighting in the political culture and the means of enforcing that culture--that will guide what is taught and how it is taught. Assessment is 
therefore the key to directing and changing education's forms, its aims and its development” (Johnson \& Kress, 2003, p. 11).

\section{Conclusions}

This research program in information literacy offers the international school library community conceptual and methodological models to use for learning about the "big picture" of information literacy instruction and assessment within and across educational systems. Studies that are grounded in perspectives within dominant discourses, such as literacy generally and new literacies particularly, will be more effective in moving the role of the school library in information literacy education forward. Those working within the school library field need to re-view their perspectives and reposition their work within more politically powerful frameworks as the research program presented in this article has done with its grounding in new literacies. Such repositioning enables joining in the grand conversations of education rather than being perceived as "other."

Although there is no one "right" or "best" method to learn about information literacy education, we presented two methods that produce initial snapshots of instruction and assessment in education systems. This type of research sacrifices depth for breadth. The questionnaire used in the instruction study was designed to be 'user friendly" in terms of teachers' time. Thus rather than being an exhaustive and comprehensive investigation, the focus was on essential constructs of interest to researchers, policy makers and professional educators. Similarly, the interview questions used to study large scale assessment programs were highly targeted to specific information that people responsible for these programs should have easy access to, thus not being overly demanding of their time. While we obtained the basic quantitative information we were seeking about present and future practices concerning the inclusion of ICT and information literacy on large scale tests, the interviews were also rich with insights about the complex challenges and dilemmas facing Ministries of Education as they work to juggle the relationship between policy, curriculum, research, instruction, and assessment programs.

All countries are seeking ways to prepare their school children to be successful in the knowledge-based economies that the Information Age is spawning. Literacy and library researchers agree that children need to learn to be information literate to be successful, but little is known about how school systems are doing in responding to this call. We suggest a theoretical framework and some research methods that can enable a beginning knowledge base of an educational system's information

literacy education. Findings will serve as a reference point for planning what schools can do better in this endeavor.

\section{References}

Asselin, M. (in press). Information literacy instruction in the middle grades. School Libraries Worldwide, 11 (1).

Asselin, M., Early, M., \& Filipenko, M. (2004). Accountability, assessment, and new literacies in the Canadian context. Manuscript submitted for publication. 
Asselin, M., \& Dreher, M. J. (2004). New literacies for the new information age: Conceptions, instruction, and teacher preparation. National Reading Conference Yearbook, 53, 115-129.

Australian Council of Deans of Education (2001). New Learning: A charter for Australian education. Canberra: ACDE.

Branch, J. (2003). Instructional intervention is the key: Supporting adolescent information seeking. School Libraries Worldwide, 9(2), 47 - 61.

Brown, G. (2001).Locating categories and sources of information: How skilled are New Zealand children? School Library Media Research. Retrieved March 2, 2005, from http://www.ala.org/Content/NavigationMenu/AASL/Publications_and_Journals/School_Li brary_Media_Research/Contents1/Volume_4_(2001)/Brown.htm

Chretien, J.P. (2002). Message from the Prime Minister of Canada. Retrieved June 202003 from www.connect.gc.ca/en/ar/1016-e-htm

Coiro, J. (2003, February). Reading comprehension on the Internet: Expanding our understanding of reading comprehension to encompass new literacies [Exploring Literacy on the Internet department]. The Reading Teacher, 56(6), 458-464. Retrieved March 1, 2005, from www.readingonline.org/electronic/elec_index.asp?HREF=/electronic/rt/2-03_column/ .

Council of Ministers of Education, Canada. (1999). Shared priorities in education at the dawn of the 21st century: Future directions for The Council of Ministers of Education, Canada. Retrieved January 27, 2003, from http://www.cmec.ca/reports/victoria99.en.stm

Hoffman, J., Paris, S., Salas, R., Patterson, E., \& Assaf, L. (2003). High stakes assessment in the language arts: The piper plays, the players dance, but who pays the price? In J. Flood, D. Lapp, J. Squire \& J. Jensen (Eds.), Handbook of research on teaching the English Language Arts ( $2^{\text {nd }}$ Ed.), (pp. 619 -630). Mahwah, NJ: Lawrence Erlbaum.

International Reading Association (1999). High stakes assessment in reading: A position statement of the International Reading Association. Retrieved February 232003 from: http://www.ira.org/pdf/high_stakes.pdf

International Society for Technology in Education (2003). National Educational Technology Standards. Retrieved March 2, 2005, from http://cnets.iste.org/

International Reading Association and National Council of Teachers of English. (1996). Standards for the English Language Arts. Newark, DE: International Reading Association. Retrieved March 2, 2005, from http://www.reading.org/resources/issues/reports/learning_standards.html

Kinzer, C. K. \& Leander, K. (2003).Technology and the Language Arts: Implications of an expanded definition of literacy. In J. Flood, D. Lapp, J. Squire, \& J. Jensen (Eds.), Handbook of research on teaching the English Language Arts ( $2^{\text {nd }}$ ed., pp. 546 - 565). Mahwah, NJ: Lawrence Erlbaum.

Kuhlthau, C. (1999). Student learning in the library: What Library Power librarians say. School Libraries Worldwide, 5(2), 80 - 97.

Lankshear, C., \& Knobel, M. (2003). New literacies: Changing knowledge and classroom learning. Philadelphia: Open University Press.

Kibby, M.W. (2000). What will be the demands of literacy in the workplace in the next millennium? Reading Research Quarterly, 35 (3), 378 - 383.

Leu, D. J. (2002). The new literacies: Research on reading instruction with the Internet and other digital technologies. In S. J. Samuels \& A. E. Farstrup (Eds.), What research has to say about reading instruction (pp. 310-336). Newark, DE: International Reading Association.

Leu, D. J., Jr. Ataya, R., \& Coiro, J. (December, 2002). Assessing assessment strategies among the 50 states: Evaluating the literacies of our past or our future? National Reading Conference. Miami, FL.

Leu, D. J., Jr., Kinzer, C. K., Coiro, J., \& Cammack, D. W. (2004). Toward a theory of new literacies emerging from the Internet and other information and communication technologies. In R. B. Ruddell, \& N. Unrau (Eds.), Theoretical models and processes of reading (5th ed., pp.1570 - 1613). Newark, DE: International Reading Association. Retrieved March 2, 2005, from http://www.readingonline.org/newliteracies/lit_index.asp?HREF=leu/

Oberg, D. (1999). The school library program and the culture of the school. In K. Haycock (Ed.), Foundations for effective school library programs (pp. 41 - 47). Englewood, CO: Libraries Unlimited.

Ontario School Library Association (1998 - 1999). Information studies: Curriculum for schools and school libraries. Retrieved March 4, 2005, from http://www.accessola.com/action/positions/info_studies/ 
Organization for Co-operation and Economic Development (2001). Schooling for tomorrow.

Reinking, D., McKenna, M. C., Labbo, L. D. \& Kiefer, B. (Eds.). (1998). Handbook of literacy and technology: Transformations in a post-typographic world. Mahwah, NJ: Erlbaum.

Schmar-Dobler, E. (2003, September). Reading on the Internet: The link between literacy and technology. Journal of Adolescent \& Adult Literacy, 47(1). Available: http://www.readingonline.org/newliteracies/lit_index.asp?HREF=/newliteracies/jaal/903_column/index.html

Tapscott, D. (1998). Growing up digital: The rise of the net generation. New York: McGraw Hill.

Topping, K. et al (2003). Policy and Practice Implications of the Program for International Student Assessment (PISA) 2000: Report of the International Reading Association PISA Task Force. Retrieved June 20, 2003, from: http://www.reading.org/advocacy/pisa.pdf

Zweizig, D. L., \& Hopkins, D. M. (Eds.). Lessons from Library Power: Enriching teaching and learning. Englewood, CO: Libraries Unlimited. 


\section{Appendix A}

\section{Teaching Information Literacy in the Middle Grades:}

Questionnaire for Teachers of Grades 6 - 7

PIN

"Information Literacy" is defined in this study as "proficiency in information retrieval, analysis, and communication in conjunction with highly developed technological skills" (Ontario School Library Association, 1999).

1. For what grade(s) do you have primary teaching responsibilities?

Grade 6

Grade 7

2. What major area(s) (over $35 \%$ each) are you responsible for teaching?

English/Language Arts

Social Studies/Humanities

Fine Arts

Sciences

Other (please name)

Generalist Elementary

3. How well prepared are you to teach information literacy skills and strategies, as defined above, to your students?
Not prepared
Neutral
Well prepared

1

2

3

4

5

4. Where did you learn about information literacy instruction? Check all that apply.

Didn’t learn about it

Teacher education program

In-service professional development

Self-learned

Other (please identify)

5. Please rate the following statements as they pertain to your school and experience by marking the appropriate box. $(\mathrm{SD}=$ strongly disagree; $\mathrm{D}=$ disagree; $\mathrm{N}=$ neutral; $\mathrm{A}=$ agree; $\mathrm{SA}=$ strongly agree)

a) Teachers, including teacher-librarians, in this school regularly plan and teach together.

b) I regularly use a resource-based and problem-based approach to teaching and learning (e.g., students consult multiple resources and research problems and issues).

c) The predominant approach to teaching in my classroom is student-centered with an emphasis on active learning.

d) I regularly collaborate with teachers, and/or teacher-

\begin{tabular}{|l|l|l|l|l|}
\hline SD & D & N & A & SA \\
\hline SD & D & N & A & SA \\
\hline SD & D & N & A & SA \\
\hline SD & D & N & A & SA \\
\hline
\end{tabular}




\begin{tabular}{|l|l|l|l|l|l|}
\hline $\begin{array}{l}\text { librarians, and/or computer teachers to teach information } \\
\text { skills and strategies to students. }\end{array}$ & & & & & \\
\hline $\begin{array}{l}\text { e) I fully understand the teaching role of the teacher- } \\
\text { librarian. }\end{array}$ & SD & D & N & A & SA \\
\hline f) I teach stages of the research process to my students . & SD & D & N & A & SA \\
\hline
\end{tabular}

6. Rate your students' (as a class) ability to apply information skills in their own work on the scale below.
Not able
Neutral
Fully able

1

2

3

4

5

7. Do you use the school library during research project assignments?

Yes

No

If "Yes", identify how: (check all that apply)
a. __ as a place for students' independent selection of resources
b. __ for the service the teacher-librarian provides of pulling resources for use in classroom or library
c. ___ as a work space for whole class, small group or individual work with the teacher or teacher-librarian
d. __ as a place for students to work independently
e. __ as a place to be taught specific research or information skills and strategies
f. ___ as a place for teachers to access information and communication technologies (e.g., video, computer, television)
g. ___ as a place to share and present students' work
h. _ Other (please list)

8. Do you consult with the teacher-librarian about resources when planning a unit?
Never
Rarely
Occasionally
Often
Always

9. Rate the degree to which the resources available to you in the school library are adequate to support your students' research projects.

Minimally supportive

Neutral

Highly

supportive

1

2

3

4

5

10. Is there a school-wide research process model in place? 
11. Indicate the extent of instruction you provide, over the course of a school year, for the following learning outcomes taken from the BC Language Arts IRP. (Answer only the section relevant to the grade(s) you teach. If you teach both grades 6 and 7, respond to both sections.)

Grade 6

None Moderate A great

deal

a) Use text and electronic media features including indices, table of contents, and key word searches to locate specific information and material.

b) Select and apply information technology tools for specific tasks.

c) Evaluate the credibility and reliability of various sources.

d) Record and organize information for specific purposes from a variety of human, print, and electronic resources into a structured presentation using more than one form of representation.

\begin{tabular}{|l|l|l|l|l|l|} 
& 1 & 2 & 3 & 4 & 5 \\
\hline 1 & 2 & 3 & 4 & 5 \\
\hline 1 & 2 & 3 & 4 & 5 \\
\hline
\end{tabular}

Grade 7

None

Moderate A great

deal

e) Demonstrate a concern for the responsible use of information technology tools and resources.

f) Locate, gather, select, and record information for specific purposes from a variety of human, print, and electronic sources.

g) Analyze information that is retrieved from a variety of electronic sources.

h) Organize and present information students have read, heard, or viewed in a variety of written and graphic forms in print and multi-media forms.

\begin{tabular}{|l|l|l|l|l|l|} 
& 1 & 2 & 3 & 4 & 5 \\
\hline & 1 & 2 & 3 & 4 & 5 \\
\hline
\end{tabular}

12. What factors or conditions enable and/or constrain your ability to teach these learning outcomes?

13. In your school, whose responsibility is it to teach information skills and strategies to students? (check all that apply)
a. Classroom teacher
b. Teacher-librarian
c. Parents
d. Principal
e. __ Learning assistance or teachers of the gifted
f. _ ICT/Computer teacher
g. __ Other (please explain) 
14. Indicate the extent of instruction that your students typically receive from either you, another teacher, and/or the teacher-librarian, over the course of a school year, in the following aspects of information literacy.

deal

$$
\text { None Moderate A great }
$$

\begin{tabular}{|l|l|l|l|l|l|}
\hline a) Evaluate websites & 1 & 2 & 3 & 4 & 5 \\
\hline b) Learn about plagiarism & 1 & 2 & 3 & 4 & 5 \\
\hline c) Access and locate information from a variety of sources & 1 & 2 & 3 & 4 & 5 \\
\hline d) Examine information for bias & 1 & 2 & 3 & 4 & 5 \\
\hline e) Use information technology & 1 & 2 & 3 & 4 & 5 \\
\hline f) Prepare reports/presentations & 1 & 2 & 3 & 4 & 5 \\
\hline g) Interpret, review, and organize information & 1 & 2 & 3 & 4 & 5 \\
\hline h) Select appropriate resources for particular purposes & 1 & 2 & 3 & 4 & 5 \\
\hline
\end{tabular}

15. Please provide an example of at one research assignment (e.g., outline or plan) that you have used, or plan to use, this year with grades 6 and/or 7. Include any activity sheets focused on developing students' information skills and strategies. Remove any identifying information about your school, district, or class and include these items in the envelope with your questionnaire. If you are require further information about this request, please contact me at 604-822-5788 or email me at marlene.asselin@ubc.ca.

16. Is there anything else you would like to add about the issue of teaching information literacy in the middle grades?

$$
\text { Yes }
$$
No

If "Yes", please describe below. Continue on back if necessary.

Thank you for your time and help in learning about teaching information skills and strategies to our students. 


\section{Appendix B}

\section{Teaching Information Literacy in the Middle Grades}

\section{Questionnaire for Teacher-librarians in Schools with Grades 6 and 7}

"Information Literacy" is defined in this study as "proficiency in information retrieval, analysis, and communication in conjunction with highly developed technological skills" (Ontario School Library Association, 1999).

1. How long have you been a teacher-librarian? years

2. What percentage of your assignment in this school is as teacher-librarian? percent

3. Rate your level of confidence in the following aspects of information literacy, as defined above, by marking the appropriate box.

Strong
\begin{tabular}{|l|l|l|l|l|l|}
\hline a) Your own understanding of information literacy & 1 & 2 & 3 & 4 & 5 \\
\hline b) Your own level of information literacy & 1 & 2 & 3 & 4 & 5 \\
\hline c) Your ability to teach information literacy to your students & 1 & 2 & 3 & 4 & 5 \\
\hline
\end{tabular}

Please rate the following statements as they pertain to your school and experience by marking the appropriate box. ( $\mathrm{SD}=$ strongly disagree; $\mathrm{D}=$ disagree; $\mathrm{N}=$ neutral; $\mathrm{A}=$ agree; $\mathrm{SA}=$ strongly agree)

\section{Learning/Teaching Environment}

a) Teachers, including teacher-librarians, in this school regularly plan and teach together.

b) Teachers in this school use resource-based and problem-based approaches to learning (e.g., students consult multiple resources and research problems and issues).

c) The predominant approach to teaching in this school is student-centered with an emphasis on active learning.

d) Teachers, teacher-librarians, and computer teachers regularly collaborate to teach students information literacy skills and strategies.

e) The instructional role of the teacher-librarian is well understood in this school.

f) The teacher-librarian is actively engaged in curriculum planning at the classroom and school level (i.e., serves on school curriculum committees).

\begin{tabular}{|l|l|l|l|l|l|}
\hline $\mathrm{D}$ & & & & $\mathrm{A}$ \\
\hline $\mathrm{D}$ & & & & $\mathrm{A}$ \\
\hline $\mathrm{D}$ & & & & $\mathrm{A}$ \\
\hline $\mathrm{D}$ & & & & $\mathrm{A}$ \\
\hline $\mathrm{D}$ & & & & $\mathrm{A}$ \\
\hline & $\mathrm{D}$ & & & & $\mathrm{A}$ \\
\hline
\end{tabular}

\section{Information Infrastructure}

a) The school and/or computer lab is fully networked.

b) The library computers offer online access to information.

c) The library offers a variety of digital and print information resources in sufficient quantity and scope to support students' research tasks.

\begin{tabular}{|l|l|l|l|l|}
\hline SD & D & N & A & SA \\
\hline SD & D & N & A & SA \\
\hline SD & D & N & A & SA \\
\hline
\end{tabular}




\begin{tabular}{|l|c|c|c|c|c|}
\hline $\begin{array}{l}\text { a) A school-wide information processing or research process model is in } \\
\text { place. }\end{array}$ & SD & D & N & A & SA \\
\hline $\begin{array}{l}\text { b) A continuum of information literacy skills and strategies is in place in } \\
\text { the school library program. }\end{array}$ & SD & D & N & A & SA \\
\hline $\begin{array}{l}\text { c) School administrators are committed to the importance of teaching } \\
\text { information literacy skills and strategies. }\end{array}$ & SD & D & N & A & SA \\
\hline $\begin{array}{l}\text { d) Classroom teachers are expected to teach information literacy skills } \\
\text { and strategies. }\end{array}$ & SD & D & N & A & SA \\
\hline e) A district-wide research process model is in place. & SD & D & N & A & SA \\
\hline
\end{tabular}

7. Approximately what percentage of grade 6 and/or 7 teachers in your school participate in collaborative program planning and teaching with you as the teacher-librarian? percent

8. How often do you teach information literacy skills and strategies to students in grade 6 and/or 7 ?

_ Never or almost never

Once a month
Once a year

Twice a month
Once a term

At least once a

week

9. Indicate the extent of instruction that you normally provide to grade 6 and/or 7 students, over the course of a school year, in the following aspects of information literacy.

deal

$$
\text { None Moderate A great }
$$

\begin{tabular}{|l|l|l|l|l|l|}
\hline a) Evaluate websites & 1 & 2 & 3 & 4 & 5 \\
\hline b) Learn about plagiarism & 1 & 2 & 3 & 4 & 5 \\
\hline c) Access and locate information from a variety of sources & 1 & 2 & 3 & 4 & 5 \\
\hline d) Examine information for bias & 1 & 2 & 3 & 4 & 5 \\
\hline e) Use information technology & 1 & 2 & 3 & 4 & 5 \\
\hline f) Prepare reports/presentations & 1 & 2 & 3 & 4 & 5 \\
\hline g) Interpret, review, and organize information & 1 & 2 & 3 & 4 & 5 \\
\hline h) Select appropriate resources for particular purposes & 1 & 2 & 3 & 4 & 5 \\
\hline
\end{tabular}

10. Indicate the approximate percent of instructional time that you give to each of the following areas of the school library program:

Promoting reading ___ $\% \quad$ Teaching information literacy___ $\% \quad$ All Other__ $\%$

11. Is there a section on report cards designated for recording students' learning experiences and/or outcomes in the school library program (either by comment or grade)?

Yes No

12. Do you as the teacher-librarian contribute any portion of the evaluation of student learning to the formal report card?

Yes No

If "Yes", please describe how you contribute to report card evaluations. 
13. Please provide an example of one research assignment (e.g., outline or plan) that you have used, or plan to use, this year with grades 6 and/or 7 . Include any activity sheets focused on developing students' information skills and strategies. Remove any identifying information about your school, district, or any classes and include these items in the envelope with your questionnaire. If you are require further information about this request, please contact me at 604-822-5788 or email me at marlene.asselin@ubc.ca.

14. Is there anything else you would like to add about the issue of teaching information literacy in the middle grades?
Yes
No

If “Yes", please describe below

Thank you for your time and help in learning about teaching information skills and strategies to our students. 
Reproduced with permission of the copyright owner. Further reproduction prohibited without permission. 